which Mr. Eric Hardy has drawn up for the Merseyside Naturalists' Association. Covering botanical vice-counties 58 and 59 , it adds new records of a number of plants. The increase of a hermaphrodite form of Bryonia dioica on the Lancashire dunes, a new unnamed Wnothera hybrid and the extinc. tion of Rumex cuneifolius (first recorded in Britain from west Cheshire, 1913) are also noted.

\section{Biological Investigations at Palao}

THE first part of the second volume of the "Studies of the Palao Biological Station" contains seven reports relating to corals, detailed descriptions of four species of Pheretima (Oligochæta) and an examination by Y. Haneda of the luminescence of shore fishes of the genus Leiognathus. In these latter the luminous body is in the form of a ring surrounding the œsophagus where it enters the body cavity. The light in the eleven species examined passes through the muscles, which are milky white and translucent. The gland has two openings from the cesophagus. Through these, luminous cocci enter and settle down, the response to outer stimuli being rapid.

Three reports deal with the biochemistry of corals, and Motoda compares the conditions in the open sea with those in the lagoon; these are preliminary reports. Motoda also studies the growth-rate of a massive coral (Goniastrea) by the multiplication of its polyps. It is a coral of the reef flat and thus subjected to tidal waters, which are studied in respect to termperature, salinity, oxygen content, $p \mathrm{H}$ and exposure to air. The oxygen production by ten polyps under varied conditions of light and depth, this due to their symbiotic algæ, gives $0 \cdot 22-0 \cdot 14$ per hour at a depth of $6 \mathrm{~cm}$. in clear weather, while under thick clouds 0.08 c.c. is consumed. Direct exposure to the sun's rays in air is successfully resisted for two hours, but nearly all polyps are killed after six hours. The growth-rate decreases with age, but most colonies died before the second count. It had previously been suggested that this decrease is correlated with reproductive activities, but this is not considered. Finally, Abe's work on Fungia is interesting as dealing with the effect of sediments.

\section{School Hygiene in Sao Paulo}

The School Health Service of São Paulo, Brazil, claims to be one of the oldest, if not the oldest, child welfare institution. By a decree of December 28, 1938, the service has been reorganized, with the enlargement of existing facilities and the creation of other services including those of mental hygiene and child guidance clinic, allergy clinic, endocrinology and nutrition clinic, dermatology and syphilis elinic, educational puericulture for students of normal and professional schools, X-ray and laboratory services, etc. During the first half of 1939 the Service, which is under the Department of Education, attended 94,108 children, made 2,286 health examinations at headquarters and 42 at home, 1,426 vaccinations at headquarters, attended 39,144 children in the Largo de Arouche School Polytechnic, 4,216 in the eye service, 5,369 in the otorhinolaryngology service, 388 in the dermatology and syphilis clinic and 3,819 in the X-ray clinic. In the School Groups, 26,276 children were examined.

\section{Vital Statistics in New Zealand}

According to the annual report of the Royal New Zealand Society for the Health of Women and Children founded by the late Sir Truby King, the birth-rate of the Dominion in 1939 (excluding Maoris) was $18 \cdot 73$ per 1,000 , the highest recorded since 1930 . The maternal mortality-rate, excluding septic abortion, was $2 \cdot 95$, and the infantile mortality-rate $3 \cdot 14$ per 1,000 births, almost the lowest ever recorded. The death-rate during the first month of life was $21 \cdot 8$, an improvement on the figure for recent years. The Society has six infants' hospitals in various parts of New Zealand, and the 138 Plunket nurses in its service saw 22,000 new cases during the most recent year and paid 170,000 visits to homes.

\section{The National Trust}

THE report of the National Trust for the year 1940-41 shows the unique position attained by this society devoted to the preservation of places of historic interest or natural beauty. Not only are bequests of land coming to the Trust upon an increasing scale, but the recent Country Houses Scheme has received important support in the transfer of the beautiful Blickling Hall, Norfolk, and its large estate, to the control of the National Trust. In the terms of Lord Lothian's will the freehold is vested in the Trust on the condition of preserving the amenities, and with the request that in the choice of tenant preference shall be given to descendants of the donor, subject to facilities for the access of the public. Death duties on large estates are now on such a destructive scale that the preservation of England's noble mansions, their period furniture, and surrounding parks can only be ensured by their transfer to a permanent society such as the National Trust.

\section{Fire Risks in Railway Trains}

THE report which Colonel A. C. Trench has presented to the Ministry of War Transport on the fire in which six schoolboys lost their lives and which destroyed three coaches of an express train on the L. and N.E. Railway on April 28 should not disturb faith in the general safety of railway travel in Great Britain. It is unfortunate, as is pointed out in Engineering of July 11, that, in the interests of economy, the reports of inquiries into the causes of railway accidents are no longer being published and circulated in the usual manner. This is doubly regrettable, for the account of the tests carried out by Colonel Trench, in spite of war conditions, is good evidence of the morale of the country.

The train in question was travelling at about 55 miles an hour when the fire began; it was stopped in about a mile and a quarter, by which time the fire had taken a firm hold on one coach. Colonel Trench refers in his conclusions to the locking of doors of unoceupied vans and of gangway and corridor doors. $\mathrm{He}$ also suggests that the wadding 